\title{
THE SUFFERING OF REVEREND EUGEN ŠUTRIN
}

\author{
Zlatko BEGONJA*
}

\begin{abstract}
Reverend Eugen Šutrin was a victim of the supremacy of the communist ideological passion that ruled the entire area of Croatia in the immediate post-war period, including the town of Privlaka near Zadar. In this imposed atmosphere, individuals and groups of people who were close to or ideologically committed to the communist principles took it upon themselves to decide on the fate of others. Quite often, their personal assessments and evaluations resulted in attacks on property and on the lives of individuals for whom they were determined to be their worldview or class enemies. There were two components involved in the case of Rev. Eugen Šutrin, who was murdered at the end of 1945: the first defined him as a worldview opponent and the second saw him as a witness to the events at the Italian concentration camp for civilian internees on Molat. The investigative actions taken against the suspects for the committed crime and the subsequent trials did not fully reveal which of the previously mentioned components was the key motive for the murder of Rev. Eugen Šutrin.
\end{abstract}

Keywords: Reverend Eugen Šutrin, Concentration camp Molat, OZN (Department for the Protection of the People), crime

\section{Introductory remarks}

The establishment and consolidation of the imposed communist government burdened the immediate post-war period in Croatia. Using the revolutionary Bolshevik method of dealing with political and ideological dissidents, the authority of the people, as well as their unquestioning followers, did not shy away from carrying out various forms of violence, repression and crimes.

\footnotetext{
* Zlatko Begonja, PhD, Associate Professor, Department of History, University of Zadar, Zadar, Croatia.
} 
In this context, the town of Privlaka was of no exception, and at the end of 1945 , the revolutionary atmosphere resulted in, among other things, the grave crime of liquidating the young parish priest that had just arrived, Reverend Eugen Šutrin. ${ }^{1}$ This example gives a credible image of how the regime functioned and, due to the imposed ideological atmosphere, how it created essential preconditions for the performance of such crimes. It is precisely because of such actions that one should insist on exposing the character of the regime, which is the basic premise for establishing a more complete picture of the relationships that prevailed during the observed period.

The course of events related to this example can also be confirmed by analyzing the activities of the dominant political structure, as well as the repressive and judicial bodies. Without understanding their actions and the given political, but equally established legal provisions on that basis, an appropriate assessment of the regime's activities cannot be made. Therefore, examples such as this one with Reverend Eugen Šutrin, in which his face sufficiently illuminated the system of government, are crucial in terms of getting a better understanding of the real aspirations to which the imposed structures of power aspired.

\section{Priesthood}

Eugen Šutrin was born on June 26, 1914 in Luka on Dugi Otok (Long Island) in the Zadar archipelago. He was the fourth of a total of seven children in the family, born to Šime and Justina. Eugen finished primary school in his hometown, after which he enrolled in the Episcopal Student Seminary in Šibenik, where he successfully attended the State Classical Gymnasium (secondary school). His education was additionally supplemented by his time spent at the Theological Seminary in Split. ${ }^{2}$ Even during the earlier periods of his life, Eugen Šutrin expressed an interest and inclination toward the Catholic priestly vocation. Given such a fact, it can be assumed that his personal commitment was additionally driven by the steady upbringing he received, mainly by his pious family. Also, it is very likely that the local parish priest, Rev. Ivo Milanja, had a significant influence on his spiritual development, since he was

\footnotetext{
$1 \quad$ This case is partly addressed in: Zlatko Begonja, Političke prilike i sudski procesi u Zadru od 1944. do 1948. Doctoral dissertation (Zadar, 2007); as well as Zlatko Begonja, Okupacija duha: Ideološka indoktrinacija u Zadru 1945. - 1955. (Zadar, 2021).

2 For more about the life and priestly activity of Rev. Eugen Šutrin see: Rozario Šutrin, Žrtve bogoljublja i čovjekoljublja (Zadar, 2002), pp. 61-67; Pavao Kero, "Ubijeni i osuđivani svećenici Zadarske nadbiskupije od Drugoga svjetskog rata do Domovinskog rata“, in: Hrvatski mučenici i žrtve iz vremena komunističke vladavine (Zagreb, 2013), pp. 441-442.
} 
a very active preacher of the Catholic organization "Eagles and Crusaders"3 during Šutrin's formative period. Namely, Orlovstvo (Orel movement) was a Catholic youth organization that began with its activities in October of 1920. It was originally founded as a fitness society, which additionally aimed for religious, moral and intellectual advancement of the youth, that is, the affirmation and promotion of Catholic ideology. However, the society's life was interrupted by the proclamation of the dictatorship of King Alexander I of Yugoslavia from $1929,{ }^{4}$ when there was a period of banning all organizations of national character as well as those of Catholic orientation in the Kingdom of the Serbs, Croats and Slovenes (SCS). As a response to the situation, an initiative was launched in Zagreb, during 1930, for the reunion and organization of the Catholic youth, which was finally realized in April of 1930 with the establishment of the Crusaders organization. The organization was primarily based on the ideas and understandings of the Crusades according to the paradigm from France, whose basic principles in Croatia were wholeheartedly and persistently promoted by Dr. Ivan Merz..$^{5}$

Rev. Ivo Milanja was born in 1899, on Dugi otok (Long Island), where he also completed primary school. He completed his secondary school education at the gymnasium in Zadar, where, as in Ljubljana, he continued to study theology. Rev. Milanja was ordained as a priest on September 22, 1923, and then served in the towns of Soline and Luka on Dugi Otok. He passed away at the beginning of $1932 .{ }^{6}$ Without a doubt, the pastoral life and moral principles propagated by Reverend Ivo Milanja, in the circumstances, left an apparent impression on the young Eugen and in that sense further encouraged and strengthened him in the final formation of his own worldviews. Following such development in life and education, Eugen Šutrin received the presbyterate from Dr. Jeronim Mileta, the Bishop of Šibenik and the Apostolic Administrator of a part of the Zadar Archdiocese, on July 17, 1938 in the Šibenik cathedral. ${ }^{7}$

\footnotetext{
3 More detailed information about the beginnings and significance of the activities of the Catholic organization Eagles and Crusaders, see: Jure Krišto, Hrvatski katolički pokret 1903. - 1945. (Zagreb, 2004), pp. 133-151; 191-198.; Lav Znidarčić, "Don Joso Felicinović i Orlovsko-križarska organizacija“, in: Život i djelo don Jose pl. Felicinovića (Pag - Zadar, 2002), pp. 181-185.

4 See: Hrvoje Matković, Povijest Jugoslavije: Hrvatski pogled (Zagreb, 1998), pp 171-177.

5 More about the life and work of Dr. Ivan Merz see in the proceedings of the symposium Pojava i značenje dr. Ivana Merza u Crkvi u Hrvatskoj (Zagreb, 1979).

6 See Šibenik’s weekly magazine Katolik, no. 4, January 24, 1932, p. 2.

7 Dr. friar Jeronim Mileta. For more on the life and priestly journey, as well as spreading of the Eagle and Crusaders' ideas dr. fra Jeronima Milete, compare: Archives of the Šibenik diocese (hereinafter: AŠD), as well as Ivo Livaković, Poznati Šibenčani: šibenski biografski leksikon (Šibenik, 2003).
} 
Namely, after concluding the Treaty of Rapallo on November 12, 1920 that was achieved between the Kingdom of SCS and the Kingdom of Italy, the City of Zadar, along with other Croatian territories, fell under Italian rule, which de facto and de jure caused the division of the metropolitan center of the Church in Dalmatia, as well as the consequent division of the Zadar Archdiocese in two parts. This event had multiple negative meanings on the quality of life and political functioning of the Croatian nationals in the area, and thus on the overall development of church conditions in the imposed divided Zadar Archdiocese. Respecting the internationally certified provisions of this agreement and the new circumstances, the Holy See passed a partial solution, and the Bishop of Šibenik, Dr. Jeronim Mileta, was appointed as Apostolic Administrator for part of the Zadar Archdiocese, that is, for parishes that belonged to the Kingdom of Serbs, Croats and Slovenes. ${ }^{8}$ At the same time, for parishes that belonged to the Italian side, which meant those in the City of Zadar, Arbanasi, Bokanjac, Dračevac, Ploče and Crno, but also on the associated islands such as Cres, Lošinj, Lastovo, ${ }^{9}$ Ivan Borzatti was appointed as the Apostolic Administrator, ${ }^{10}$ and from 1926 to 1948, he was succeeded in that position by Petar Dujam Munzani. ${ }^{11}$

Reverend Eugen Šutrin celebrated his first Mass in his hometown of Luka on August 3, 1938. As early as September 2, 1939, Bishop Mileta issued a decree appointing Šutrin administrator of the parish of Molat and servant of the town of Brgulje, where he remained in capacity until 1945. Among other things, the decree of Bishop Mileta stated the following: "I appoint you as the administrator of the parish of Molat and as the procurator of Brgulje. Your first service is a big one, because you have to take care of the souls in two parishes, which requires both zeal and sacrifice. I hope that you will justify the trust I place in you with this appointment."12

8 He was appointed by the Holy See as the Apostolic Administrator of a part of the Zadar Archdiocese, with the rights of a residential bishop, April 2, 1922. See: Juraj Batelja, Zadarska trilogija, Book 2 (Zagreb, 2014), p. 8; Archives of the Šibenik diocese; Ivo Livaković, Poznati Šibenčani: šibenski biografski leksikon (Šibenik, 2003).

9 See: Pavao Kero, Pregled povijesti Zadarske nadbiskupije od 1918. do 1948. (Zadar, 2006), pp. 6-10.

10 Ivan Borzatti held the position of Apostolic Administrator of the Italian part of the Zadar Archdiocese until his death on February 17, 1926. See: J. Batelja, Zadarska trilogija, 9.

11 Petar Dujam Munzani, Apostolic Administrator, who, since 1932, became the residential Archbishop of the newly established Zadar Archdiocese according to the bull of Pope Pius XI. Pastorale munus from August 1, 1932. He held that position until 1948. This bull abolished the Zadar metropolis, and the established Zadar archdiocese was directly subordinated to the Holy See. For more information: J. Batelja, Zadarska trilogija, 9.

12 Archives of the Šibenik diocese, Jeronim Mileta Fund, Apostolic Administrator of a part of the Zadar Archdiocese, Appointment, no., 3642/AA, from September 2, 1939. 
The appointment and service that he received found him in the position of parish Administrator of the parish of Molat, during the Second World War. Consequently, he was a contemporary of the events when the Italian fascist authorities, as part of the establishment of a series of concentration camps for civilian internees on the eastern Adriatic coast, formed, among others, such a transit camp on the Island of Molat. ${ }^{13}$ It was founded on the direct orders of Giuseppe Bastianini, the governor of Dalmatia at the time, ${ }^{14}$ who, on June 13, 1942 determined that there was a need to establish this type of camp. The camp began operating on June 30,1942, ${ }^{15}$ and existed until the moment of dissolution via facti, September 8, $1943 .{ }^{16}$ The role of Rev. Eugen Šutrin in this mentioned period was related to his frequent visits to the Molat Camp and his priestly care of the internees. This included performing religious rites, but also, when necessary, preparing a decent funeral for the deceased detainees. ${ }^{17}$ Therefore, in addition to performing his priestly duties, he also became a direct witness to the events that took place at the Camp. Witnessing these events had certain consequences on his life path.

The course of events related to the Molat Camp, which in this context referred to the role of Rev. Eugen Šutrin, can be seen from the letters sent to him at that time by Bishop Mileta. Thus, a letter from July 1942 stated: "To the Reverend Administrator of the Parish of Molat. I received your report from 6. o. mon. no. 74. I am glad that you have already made yourself available for pastoral care at the Camp. The service is very delicate and difficult, so I recommend

\footnotetext{
13 Along with Molat, there were camps on Rab, Bakar, Kraljevica, Rijeka, Zlarin, Mamula, Prevlaka, as well as transit camps on the Island of Osljak in Zadar, then on Murter, Biograd, Vodice, Divulje, as well as an unfinished one on the Island of Ugljan. For more about the camps, reasons for their establishment and functioning, see: Carlo Spartacco Capogreco, Mussolinijevi logori - Internacija civila u fašističkoj Italiji (1940. 1943.) (Zagreb, 2006); Josip Grbelja, Talijanski genocid u Dalmaciji - Konclogor Molat (Zagreb, 2004).

14 In the annexed area of Dalmatia, fascist Italy, simultaneously, with the signing of the Treaty of Rome, on May 18, 1941, established the andministrative and political administration of the Governorate of Dalmatia (Governo della Dalmazia) with headquarters in Zadar. The governor was a prominent member of the fascist party, Giuseppe Bastianini, and at the time directly subordinate to the party and state Italian leader Benito Mussolini.. The governorship was dissolved by a decision of the new Prime Minister of the Kingdom of Italy, Marshal Pietro Badoglio, dated August 7, 1943. See: Giovanni Eleuterio Lovrovich, Zara dai bombardamenti all'esodo (1943.-1947.) (S. Lucia di Marino, 1974).

15 See: Dragovan Šepić, “Talijanska okupaciona politika u Dalmaciji (1941.-1943.)“, Putovi revolucije (1963.), No. 1-2: 233.

16 Date of public announcement of the military capitulation of the fascist Kingdom of Italy.

17 On the issue of the number of deaths in the camp, see: Zlatko Begonja, "Proturječja u svezi s brojem žrtava fašističkog koncentracijskog logora na otoku Molatu", in: Logori, zatvori i prisilni rad u Hrvatskoj/Jugoslaviji 1941. - 1945., 1945. - 1951. (Zagreb, 2010), pp. 91-110.
} 
that you be zealous and prudent. You, as the pastor, have all the powers for those who now reside in the parishes of Molat and Brgulje. As I telegraphed today, I authorize you - to think sub divo ${ }^{18}$ within the Camp. Regarding the consecrated plaque, you can take it out of the altar in the church and later send it here and you will receive a new plaque if you need it. I also telegraphed Rev. Šime Sturnela today, the ordained priest in Sutomišćica, to immediately go to Molat. He will help you serve in Molat and Brgulje and with the believers at the Camp. Share the work with him as you see necessary. Strive, as a zealous priest, to offer confession to those nearing death. Let's hope that there will not be those kinds of situations. In the event of an Orthodox death, you know articulo mortis ${ }^{19}$, therefore, you can conduct confession. Regarding funerals, deny only those who publicly reject the sacraments. Otherwise, in such cases, make sure that if someone refuses, it does not come out in public." In addition, he added the following text by hand: "Report all of the deaths that take place in the Camp to me. Report them to me de jure. Also, enter the deaths into the respective parish Centres, Molat or Brgulje, according to the territory." ${ }^{20}$

Later on, in August 1942, he sent a letter to the parish office in Molat with the following content: "I ordered Rev. Šime Sturnela to return to Sutomišćica, because pastoral care at the 'Camp' is regulated differently. I think that Rev. Sturnela is already home. Let there be no difficulty concerning the cemetery that the government intends to build. In doing so, let the church regulations on cemeteries be enforced. One part needs to be set aside immediately for non-believers and for those who will be denied a church funeral. The undersigned gives the parish Administrator the authority to bless the mentioned cemetery when it is finished. Let me know, as soon as possible, the names of those who have died and indicate which parish they came from." ${ }^{21}$ The letter that was delivered in September of 1942 to the parish office of Molat contained the following, among other things: "As for the expansion of the local cemetery, let the Reverend present this need to the Camp's Administration and let them take over. The undersigned does not deem it appropriate to undertake any part in this business. On the other hand, I have heard that the number of detainees will now be reduced because they will be distributed in several other places and some will be released home. Therefore, there will be less of a need to expand the cemetery. The undersigned appreciates that the Reverend ar-

\footnotetext{
18 Under the open sky, that is, under God.

19 At the time of death, on his deathbed.

20 Archives of the Zadar Archdiocese (AZDN), without foundation labels, Molat Parish Records 1934-1969, Bundle 1942, letter no. 1834/A.A., Šibenik July 10, 1942, signed by Bishop and Apost. Adm. Fr. Jeronim.

21 Archives of the Zadar Archdiocese, Bundle 1942, letter no. 1984/A.A., Šibenik August 4, 1942, signed Fr. Jeronim.
} 
ranged the burials of the deceased Orthodox, in the way that their bodies were placed in a part of the cemetery that was designated for non-believers."22 This period of war and the functioning of the Camp, that is, the priestly rights that Rev. Šutrin was supposed to perform in his parishes and within the Camp, demanded full coordination with Bishop Mileta. The Bishop's letter from October 1942 was written in this context, in which the Parish Administrator of Molat was told: "As for the priest of "Campo di Concentramento (Concentration Camp)" I envisioned sending the ordained priest Rev. Sturnela to help you serve in Brgulje, or Molat, so that you would be freer for the pastoral care needed at the Camp. But, as you already know, the prefecture and the governorate in Zadar did not want to allow it; instead they wanted and demanded that a priest from Zadar come there for the detainees at the Camp. I am very sorry that the internees do not have spiritual consolations as this time, but it is not my fault. There is nothing I can do about this. If the internees complain about this, tell them what is going on. On the other hand, I cannot allow for the parishioners of Molat and Brgulje to be left without Holy mass on Sundays and holidays. You are their pastor and you are required to serve them first. Feel free to pick a day out of the week and to go to the Camp to serve Holy mass, if that is what they want. It certainly is not honorable for you to show up to the Camp accompanied by armed soldiers. The cemetery there, as you have already been told, was desecrated. Therefore, from now on you will need to bless the grave in question before a burial, or for burials in the ground, you will need to bless the land, that is, the excavated grave. As for the oil for eternal light, there is an Order from the governorate in Zadar according to which each parish in which the Holy sacraments are kept, and located in a place where there is no electric light, is entitled to 12 liters of oil per year for eternal light." ${ }^{23}$

Likewise, Bishop Mileta warned in a letter from May 1943, that the Dean's office would "urgently send to all subordinate parish offices in transcript the circular from the $22^{\text {nd }}$, in order to inform the people in a convenient way, for the believers to do what they can, at least by praying in order to avoid what they say is coming". In that letter, the Bishop directly referred to the decree that the Italian fascist authorities had previously sent to the public, warning that all men aged 21 to 50 coming from the Zadar province (Provinzia di Zara $)^{24}$ be interned as hostages on Molat, if the sabotage by the rebels con-

\footnotetext{
22 Archives of the Zadar Archdiocese, Bundle 1942, letter no. 2294/A.A., Šibenik September 21, 1942, signed Fr. Jeronim.

23 Archives of the Zadar Archdiocese, Bundle 1942, letter no. 2460/A.A., Šibenik October 14, 1942, signed Fr. Jeronim.

24 See more: Zlatko Begonja, Političke prilike i sudski procesi u Zadru od 1944. do 1948., Doctoral dissertation (Zadar, 2007), pp. 30-31.
} 
tinues. ${ }^{25}$ In June 1943, a letter was sent to the Parish Office of Molat as well. ${ }^{26}$ Another letter from the Bishop indicated the development of conditions involving priests on the Island of Molat, even those who were not connected to the events in the area of the mentioned Italian fascist camp for civilian internees. Thus, in a letter to Rev. Šutrin in July of 1943, Bishop Mileta mentioned: "I have been informed that Rev. Frane Paro, pastor of Zapuntel ${ }^{27}$ is in Zadar and that he is waiting for his passport for $\mathrm{Pag}^{28}$ because he does not intend on returning to the parish. I immediately wrote to him in Zadar, telling him that I do not permit him going to Pag. If he thinks that Zapuntel is dangerous, I will send him to another parish, but he is not allowed to go to Pag. In the meantime, I am giving you the parish area of Zapuntel until I see if Rev. Paro will be returning there - the parish with a special priest. I will try to resolve this as soon as possible. You need to take the opportunity when there are fewer and fewer priests." 29

What is of special significance in the aforementioned correspondence between Bishop Mileta and the Administrator of the Molat parish, Rev. Eugen Šutrin, are the certain details that provide a more credible insight into the development of events, especially regarding priestly activity in the Italian fascist camp for civilian internees. In this regard, it is important to emphasize that Bishop Mileta appreciated the care that Rev. Šutrin showed toward the internees. Especially because he made himself available and performed spiritual services, to the extent possible, in order to support and help the detainees gain some much desired spiritual peace, even in difficult circumstances. Another significant detail can be spotted from the presented letters, and that is the need to expand the local cemetery. Bishop Mileta suggested that the Camp administration should take over the expansion. The Bishop also stated that the cemetery was desecrated, although it was not possible to determine who would commit such a dishonorable act. Therefore, it should be noted that if the

\footnotetext{
25 Archives of the Zadar Archdiocese, Bundle 1943, letter no. 1007/A., Šibenik May 24, 1943, signed Fr. Jeronim. The full text in Italian is transmitted in part of this letter.

26 Ibid., letter no. 15, from June 6, 1943, signed by Dean Rev. Ivo Sivlestrić.

27 Place on the Island of Molat.

28 Pag is a place - a town on the Island of Pag. During the Second World War and with the signing of the Treaty of Rome, between the Independent State of Croatia and the Kingdom of Italy, on May 18, 1941, it fell under the administration of the Independent State of Croatia. At the time of the above request of Rev. Frane Paro, the Italian fascist army was in Pag. This issue can be seen in numerous literature, such as the ones singled out here: Vjekoslav Vrančić, Branili smo državu, First book (Barcelona-Munich, 1985); Bogdan Krizman, Ante Pavelić i Ustaše (Ljubljana, 1986), and similar.

29 Archives of the Zadar Archdiocese, Bundle 1943., letter no. 1318/A.A., Šibenik July 23, 1943, signed Fr. Jeronim.
} 
Camp's Administration was really committed to the expansion of the cemetery; logically it would then exclude the possibility of its desecration on their part. Equally, it would be difficult to expect that the local population, imbued with and loyal to their religious and traditional values, although burdened by the threat of war and all its consequences, could take part in such an act. By excluding, or simply questioning such two possibilities, which would mean putting them under these conditions outside the realistic framework, there is still another possible direction to consider when clarifying this problem. Given the war situation, it is necessary to consider the possibility that the act was motivated solely by ideological and worldview reasons with a deliberate intention of targeted sabotage, which was to produce greater dissatisfaction among the locals and encourage them to certain forms of retaliation. In that case, the possible perpetrators could be those who later came to the area due to the war with the adopted prejudice of disrespect for the domestic cultural, religious and civilizational heritage, and the spread of such a worldview or isolated individual domicile locals who, under the burden of the newly imposed ideological matrix, have in the meantime voluntarily, or under pressure, renounced, their traditional and religious heritage. Given that no explicit evidence has been found that unequivocally points to the perpetrators of this act, these last considerations associated with the previous ones remain only in the domain of assumption, but even such should not be rejected a priori in a comprehensive sequence analysis.

\section{Murder during peacetime}

With the end of the War in the Zadar area, ${ }^{30}$ which was followed by the extremely aggressive treatment of Catholic priests carried out by the newly-established so-called People's government at the time, ${ }^{31}$ in reality, the revolutionary-Bolshevik structures with the aim of imposing communist ideological and worldview principles, resulted in the violent murder of Rev. Eugen Sutrin, which took place on November 26, 1945. This event was preceded by the circumstance related to the parish of Privlaka, near Nin, when it was left without its former priest, Rev. Ante Matacin, on November 1, 1944. He was arrested by the People's government and sentenced to death in the first half of 1945 in an urgent procedure, due to his alleged collaboration with the Ustashe

\footnotetext{
30 Officially after the Zadar partisan detachment entered the city of Zadar on October 31, 1944.

31 For the position of the Catholic Church and the attitude towards the clergy in communist Yugoslavia, see: Miroslav Akmadža, Katolička crkva u komunističkoj Hrvatskoj: 1945. - 1980. (Zagreb - Slavonski Brod, 2013).
} 
during the War. After his appeal of the proceedings and the sentence, the verdict was changed; this ultimately sentenced him to many years in prison. ${ }^{32}$ It is especially important to note that during the period of the war, Rev. Ante Matacin, according to his personal testimony, tried in various ways to help the internees on Molat, together with Rev. Eugen Šutrin. In this sense, he recorded the course of events that remained permanently etched in his memory and that refer to that period. Thus, among other things, he emphasized his satisfaction at the time with the proclamation of the Independent State of Croatia on April 10, 1941, and stated: "Who is happier and more satisfied than I am, as are all the people. The age-old wishes of our martyred people are being ful-

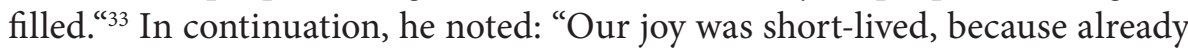
on Easter afternoon, Italian tanks entered into my parish of Privlaka, near Nin. It is impossible to describe the pain that I felt at the time, and especially when I had to, helplessly, with a larger group of people, watch the rude and, intoxicated with victory, Italians as they removed the Croatian flag, 12 meters long, from the newly-set mast in front of the church as they raised the Italian flag, which was disgusting to all of us, with military honors." According to Rev. Matacin, the circumstances created a need for younger people from Privlaka to flee across Velebit with the intention of joining the Croatian army. Due to this, the Italians issued a proclamation warning that they would arrest the parents of those young men who left the town, which in several cases, they had already done. This form of blackmail resulted in many of these young men returning, solely to save their parents from Italian captivity. Reverend Matacin described the development of these circumstances: "The Italians now blame me for the displeasure of the people, and have forbade me to leave the house at night." He further stated: "Now they have begun arresting, individually and in masses, especially from the Šibenik area, and they are taking them to the concentration camp on the Island of Molat. It is so sad to watch, how they brutally treat this world of ours. I once met up with my colleague in Zadar, Rev. Šutrin, pastor on Molat, when they led one larger group for Molat. The people from Zadar and Italians frantically shouted: Fuori dalle muraglie nel mare, - which means, into the sea with them. Reverend Šutrin came to Zadar often, where we would meet up and visit the Zadar pharmacies. Together, we

\footnotetext{
32 On the imprisonment of Rev. Ante Matacin, see: Pavao Kero, "Ubijeni i osuđivani svećenici Zadarske nadbiskupije od Drugoga svjetskog rata do Domovinskog rata", in: Hrvatski mučenici i žrtve iz vremena komunističke vladavine (Zagreb, 2013), p. 449.; Zlatko Begonja, Političke prilike i sudski procesi u Zadru od 1944. do 1948., p. 165.

33 Establishment and duration of the Independent Croatian State, for more information: Bogdan Krizman, NDH izmedu Hitlera i Mussolinija (Ljubljana, 1986); Bogdan Krizman, Ustaše i Treći Reich, books 1 and 2, (Ljubljana, 1986); Marko Sinovčić, NDH u svietlu dokumenata (Buenos Aires, 1950 - Zagreb, 1998).
} 
would acquire various medicines, which he would then bring back to Molat and distribute to the poor internees. ${ }^{34}$

These interesting but also intriguing lines from Matacin's records, in addition to pointing to the fact that Rev. Šutrin played an extremely positive role in the care of camp detainees, also point to another dimension of the problem that cannot be left aside in this analysis. Namely, as previously mentioned, Rev. Ante Matacin was arrested and convicted in peacetime by the national authorities on charges of collaborating with the Ustashe during the War, but at the same time he was suspected by the Italian fascists of aiding and abetting dissatisfaction with them, all in favor of the Ustasha regime. In this way, Reverend Matacin found himself in a paradoxical situation; he was considered an opponent of two totalitarian regimes, fascist and communist, and all this in favor of the third, Ustasha regime, which in a formal sense, through the War, was an official partner of the fascist regime. It is also worth noting how it was during the initial War period, that there was active close cooperation between military formations of Italian fascists and Serbian Chetniks in certain areas, as well as their associated Yugoslav-oriented communists, which provides this case with an additional level of complexity that requires a more thorough approach to this issue. ${ }^{35}$

Since Reverend Šutrin's exceptional care for the detainees in the fascist concentration camp for civilian internees on Molat was recorded and confirmed on several occasions, Bishop Mileta appointed him, the proven diligent priest, in a specific situation, especially related to the parish of Privlaka, as the new Administrator of that Parish. This apparently happened on November $19^{\text {th }}$ or $20^{\text {th }}$ of 1945 , although no document confirming this has been found, the events that followed indicate the possibility of the mentioned dates. ${ }^{36} \mathrm{~A}$ few days later, on November 23, 1945, Bishop Mileta delivered a letter informing him that he also granted him authority over the parish of Vir. ${ }^{37}$ Six days later, the Bishop received a short official notification from the Dean's office in Nin, signed by Rev. Ivo Nikpalj, about the murder of the parish priest, Rev.

\footnotetext{
34 Taken from: Fr. Ante Matacin, Neke crtice iz moga života i slučaj profesora Draganovića (Ontario, 1968), p. 4., 5.

35 See the level and forms of fascist-Chetnik-Communist cooperation: Zlatko Begonja, " $U$ Srbu su 27. srpnja napadnuti Hrvati i Hrvatska“, in: Dossier Boričevac, Josip Pavičić, ed. (Zagreb, 2012), pp. 226-243.

36 The original document on the date of the appointment was not found, but according to other documentation, as well as notes of contemporaries (Ante Matacin, Rozario Šutrin), it can be concluded that he was appointed in that time period.

37 Archives of the Šibenik diocese, Fund Jeronim Mileta, Appointment document no. 916/A.A., from November 23, 1945, signed Fr. Jeronim.
} 
Eugen Šutrin..$^{38}$ On December 3, 1945, the Bishop replied to this letter stating that he had already heard of Rev. Šutrin's death, therefore, given the new circumstances, he indicated how he is handing over all powers for the parishes of Privlaka and Vir to Rev. Nikpalj. ${ }^{39}$

It is important to emphasize that the violent murder of the parish priest, Rev. Šutrin, was briefly described by Rev. Ante Matacin, where he stated, among other things: "This ideal and young priest was killed in the most horrible way in Privlaka, carrying the Holy viaticum, five days after he came to Privlaka as a pastor. The partisans called him sick at night, killed him and threw him into the sea. The sea washed the body up to shore, from where they took him in order to drown him in the depths of the sea. This was right before Christmas in 1945. The people were indignant at this crime and looked for the culprits. The partisans then came up with a hellish thought and threw it among the people. They stated that the crime was organized between my sister and the Ustashe, and she was arrested and abused in the most horrible way and taken to prison". ${ }^{40}$

Before continuing the detailed analysis related to the course of events that preceded this crime, as well as the resulting consequences, it should be noted that the observed period was filled with an atmosphere of fear for the local population, which was systematically and purposefully imposed by all levels, that is, structures of the People's government, as a logical consequence of the functioning of the established totalitarian regime. The new parish priest in Privlaka, who, consequently, came under attack from local party henchmen, shared the fate of such circumstances. Namely, the established atmosphere encouraged ideological followers. They competed in behaviors and actions through which they intended to flatter the authorities and thereby show their impeccable commitment. Influenced by the growing passions that mixed ideological and popular revenge, the two party activists granted themselves the right to settle accounts with the priest. ${ }^{41}$ The crime they committed had its origin in the hatred they received through communist ideological indoctrination, which, among other things, considered religion a particularly dangerous opponent for the unhindered realization of the formation of a new social order and a man so educated in it.

\footnotetext{
38 Ibid., letter no. 5., from November 29, 1945.

39 Ibid., letter 857/A.A., from December 3, 1945.

40 Fr. A. Matacin, Neke crtice iz moga života i slučaj profesora Draganovića, pp. 5, 6.

${ }_{41}$ The predominance of ideological-popular passion and the resulting atmosphere of fear, see: Zlatko Begonja, Okupacija duha: Ideološka indoktrinacija u Zadru 1945. - 1955. (Zadar, 2021)
} 


\section{Investigative actions and court proceedings against the accused}

The credibility of the previous allegations is best shown by the results that emerged after the official investigations, which were launched by the People's government with the aim of discovering the perpetrators of this crime. In that context, Stoša Matacin was immediately suspected of the murder, the sister of the former parish priest of Privlaka, Rev. Ante Matacin. The reasons that brought her to such a position, as it stood according to the testimonies of individuals, ${ }^{42}$ were primarily found in the aggressive expressive outbursts of a separate part of the locals, who had previously expressed a negative attitude towards her, mainly due to their undisguised unacceptability of Rev. Ante Matacin. The extent to which such considerations had their history, and thus a crucial role in this case, was evident from the letter of the Municipal Committee of CPC Nin from June 1945. Namely, such was submitted to the District Committee of CPC Zadar, and in the first place it offered a detailed account of the political situation in the area of responsibility of the said $\mathrm{Mu}$ nicipal Committee. The following was particularly emphasized: “The people still have a poor outlook on Priest Matacin's sister being free." ${ }^{\prime 3}$ This allegation undoubtedly indicates the existing intention of some locals, as well as representatives of the People's government, to settle accounts at all costs with Stoša Matacin, whom they considered suspicious because of her brother, that is, an undesirable person in this local environment.

Under such an atmosphere, they initially managed to directly influence the investigative bodies to classify the person named as the only and most responsible person for committing this crime. However, the investigative bodies received contradictory information from the other part of the locals. Therefore, a procedure for establishing the real facts was initiated and this is why the investigator, upon the authorization of the Public Prosecutor of the $\mathrm{Za}$ dar District, issued a decision on the appointment of an investigative-medical committee. The investigation yielded results which, on November 27, 1945, stated, inter alia, that the dead body: "There are numerous bruises on his back, which were inflicted by some kind of hard object. There are three rifle or pistol bullet wounds on the back of the head, and three exit holes on his face. All bullets were fired one after the other at a short distance, which is known by the shape and color of the entrance opening." ${ }^{\prime 4}$ The following witnesses were

\footnotetext{
42 HR-State Archives in Zadar, f. 465., Kotarski narodni sud Zadar 1945-1948., box no. 101 - 200., file Kk 129/46. Allegations are from the testimony of some locals who were located within the observed court file.

43 HR- State Archives in Zadar, f. 309., Kotarski komitet KPH Zadar, Files of the municipal Committee of the Croatian Communist Party Nin, Misc., letter no. 85., from June 18, 1945.

44 Ibid., Record from November 27, 1945, Kk 129/46/2.
} 
summoned during the official investigation: Slavka Šutrin, Marija Bučenović, Mara Begonja and Mate Skoblar. They gave their statements regarding the actions that immediately preceded the murder of the parish priest Šutrin. Following these events, the District Department for the Protection of the People for Zadar ${ }^{45}$ launched its own investigation, and in that sense, they interrogated the following four people: Slavka Šutrin, Marko Kolanović (Alexander), Frane Mustaća (of the late Ive) and Marija Bučenović. ${ }^{46}$ In this case, as well, witnesses cited their views on events that took place before the crime was committed. Furthermore, on November 29, 1945, it was Bene Skoblar's (of the late Guge) turn, in the capacity of the village Attorney General, who formulated an indictment for Stoša Matacin in a written submission to the District Public Prosecutor. ${ }^{47}$ Given such circumstances, Stoša Matacin was in pre-trial detention the whole time, while on December 10, 1945, the actual suspects in the crime were detained, Ivan Pavlović Đani and the next day, Pere Curko. ${ }^{48}$ Subsequently, on December 12, 1945, the Zadar District Public Prosecutor issued a decision terminating the criminal proceedings against Stoša Matacin, which meant her release from pre-trial detention.

Given the development of events, but also the need of obtaining a complete picture, it is necessary to briefly highlight the basic data on the socio-political positions of the officially suspected perpetrators at the time when they decided to perform the mentioned act. The Municipal Committee of CPC Nin proposed Ivan Pavlović Đani for admission to the Communist Party of Croatia (CPC), in April of $1945 .{ }^{49}$ For this occasion, the proposer submitted to the District Committee of CPC Zadar the characteristics of the proposer in which his war path was emphasized and his full commitment to the People's Liberation Movement was especially emphasized. ${ }^{50}$ Based on these characteristics,

45 See the role and significance of the Department for People's Protection: Zdenko Radelić, Obavještajni centri: Ozna i Udba u Hrvatskoj (1942. - 1954.), Books 1 and 2 (Zagreb, 2019); William Klinger, Teror narodu: Povijest OZNE, Titove političke policije (Zagreb, 2014). For the District Department for People's Protection Zadar, see: Zlatko Begonja, Okupacija duha: Ideološka indoktrinacija u Zadru 1945. - 1955. (Zadar, 2021), pp. 24-27.

46 HR-State Archives in Zadar, f. 465., Kotarski narodni sud Zadar 1945-1948., box no. 101 - 200., file Kk 129/46/5., letter from the Department for People's Protection, no. 2929 from November 28,1945.

47 Ibid., Kk 129/46/14. The indictment of November 29, 1945 was worded on four sheets.

48 Ibid., Kk 129/46/17. Arrested on December 10, 1945 and December 11, 1945.

49 The basics of the Yugoslav Communist Party and Croatian Communist Party, among other things see: Rječnik historije države i prava (Zagreb, 1968), pp. 412-417.

50 HR-State Archives in Zadar, f. 309., Kotarski komitet KPH Zadar, Files of the Municipal Committee of the Croatian Communist Partz Nin, Misc., letter from April 5, 1945. 
the nominee was admitted to the Party in July of the same year. ${ }^{51}$ The other perpetrator, Pere Ćurko, was admitted into the communist party according to a letter from the Municipal Committee CPC Nin, in November of 1945. His characteristics also state that he was extremely prone to and acted on the line of the People's Liberation Movement..$^{52}$ By letter dated September 1945, which was submitted by the Municipal Committee of CPC Nin to the District Committee of CPC Zadar, a list of Party members was presented "who are on the field, and the function they perform in the Party and organizations outside of the Party." One of the first mentioned members was Ivan Pavlović Đani, in the function of the secretary of the Municipal Committee of CPC Nin and secretary of the Municipal Board of the People's Front of Yugoslavia Nin..$^{53}$

The sequence of proceedings regarding the investigative actions continued in December 1945 with the testimonies of the suspects at the District Department of the Department for the Protection of the People for Zadar. Thus, Pere Curko, among other things, stated the details under which circumstances and in what way the act was committed. In that sense, he stated: "On the $26^{\text {th }}$ of November, that year, Pavlović and I were playing bocce that afternoon in Nin. During the game, that warmed us up quite a bit, and I think we drank wine, Pavlović told me that a new pastor had come to Privlaka and that he wants to kill him. I immediately accepted that and answered 'Let's go'”. After that, they went to Privlaka and arrived at the pastor's house, where Curko asked the pastor to come outside and to go with them, telling him the reason why they came, and he stated: "A horse hit my mother, so, go and recommend her soul as soon as possible." He further confirmed: "We headed towards the sea, towards Cape Kulina, and after about 300 meters, I pulled out a gun and immediately fired one bullet into Rev. Eugen's head, after which he fell dead. We then dragged him to the sea, where there was a little boat, put him on the boat, and drove him about 400 meters from the coast, tying a stone around his neck, and we threw him overboard." Ivan Pavlović Đani gave an almost identical statement to the development of this event. ${ }^{54}$ The report of the Department for the Protection of the People was forwarded to the Public Prosecutor of the Zadar District, where, among other things, it was concluded about the accused: "Although the investigation could not determine possible accomplices, there is no doubt that the defendants in the

\footnotetext{
51 Ibid., letter from July 10, 1945.

52 Ibid., letter from November 13, 1945.

53 Ibid., letter no. 27/45., from November 12, 1945, See more about the United People's Liberation Front (JNF): Rječnik historije države i prava (Zagreb, 1968), pp. 506-507.

54 HR-State Archives in Zadar, f. 465., Kotarski narodni sud Zadar 1945-1948., box no. 101 - 200., file Kk 129/46/21/22., Record from the Department for People's Protection from December 21, 1945.
} 
commission of this cruel crime were motivated by their hostile conceptions, which was formed in them by poor upbringing in a hostile environment." ${ }^{\prime 5}$ It is necessary to draw attention to two particularly interesting details. The first is the one that says that the victim was killed by one shot, which is a significantly different allegation from the one formulated by the aforementioned investigative-medical commission, in which it was established that there were three shots. Furthermore, it was alleged that the crime was committed out of hostile motives, which allegedly stemmed from the perpetrator's upbringing in a hostile environment. This would actually mean that Curko and Pavlović inherited their hatred of the Catholic Church and priests from a regime that at the same time the newly established People's government claimed to have actively worked with priests against communist revolutionary affiliations and actions. Therefore, in this case, it could have only been a targeted attempt to cover up the doctrinal non-acceptance of the Church and the clergy by the communist authorities, and all this so that the undoubted criminal procedure would not be linked to the current People's government.

In January of 1946, the suspects were questioned by the Zadar District Public Prosecutor, where they repeated their earlier statements, with the addition of: "The biggest impetus for this act was given to us by the fact that, just those days, the "pastoral letter"came out, which provoked anger in the people toward the corrupt clergy, so it affected us a lot too, and it was only under this impression that we decided on this act." ${ }^{36}$ It is also interesting that, in this statement, both of them persistently emphasized that they did not agree with anyone to commit the crime, but that it was exclusively their own initiative..$^{57}$ Therefore, the statement that was so emphasized is especially intriguing, insofar as the Department for the Protection of the People had already stated, that in its investigation, they did not notice that the suspects had helpers. According to the investigative results, the perpetrators really had no collaborator, which was also confirmed by the statements of the witnesses; however, this does not in any case mean that the established atmosphere and certain local party bodies could not have played the role of instigators for the commission of the act. It is precisely the emphasis that was placed on the fact that no one else was involved in their activity that makes it necessary to express a certain doubt in the veracity of such allegations.

\footnotetext{
55 Ibid., Kk 129/46/23, Indictment of the District Department for People's Protection for Zadar, no. 3330, from December 31, 1945.

56 For the content and significance of the pastoral letter see: Miroslav Akmadža, Katolička crka u komunističkoj Hrvatskoj 1945. - 1980. (Zagreb - Slavonski Brod, 2013), pp. 32-38.

57 Ibid., Kk 129/46/25, Record compiled by the Zadar District Public Prosecutor, from January $11,1946$.
} 
Based on the performed investigative actions, at the beginning of March 1946, the Zadar District Public Prosecutor submitted to the Zadar District People's Court ${ }^{58}$ a letter with a list of criminal proceedings against the suspects for further proceedings. ${ }^{59}$ This was followed by an indictment against Pere Ćurko and Ivan Pavlović Đani, which was formulated by the Public Prosecutor of the Zadar District where the reasoning stated: "Ćurko Pere fired three revolver bullets into the back of Rev. Eugen's head. So, therefore, after mature reflection, they took another/s life." In continuation, it is accentuated that: "The accused only deny, that is, they state, that only one bullet was fired at the late Rev. Eugen, but in that regard, their defense is unfounded, because from the medical findings it can be seen that the late Rev. Eugen was killed by three revolver bullets. They are trying to justify their grave crime with alleged intoxication, pointing out that at the time when they made the decision to kill the late Rev. Eugen, they were in a heated state, due to playing bocce and drinking wine while playing the game. This kind of defense is completely naive, and the allegation of the defendant Curko where he thinks that they were obviously drinking wine during the game, is fabricated, because he himself is not sure about that, whereas the co-accused Pavlović does not mention that they drank wine." ${ }^{60}$ In April, this was followed by the main oral hearing before the District People's Court in Zadar, in which the accused Pere Curko, in addition to the defense already presented, gave a completely new detail: "When defendant Pavlović told me let's go kill the priest, he told me that he was a spy in the Molat Camp." After that, the testimony was given by Ivan Pavlović Đani, who also stated the same: "When I told the accused Curko that a new priest had come to the village and that we were going to kill him, I told him that he was a spy on Molat. I have heard this spoken by the people." At the end of the trial, the first-instance verdict was pronounced "finding the accused guilty as in the indictment and sentencing each of them to 14 (fourteen) years of imprisonment with forced labor and 8 (eight) years of loss of civil and political rights, except parental rights." ${ }^{11}$ With the exception of the sentence imposed here, it is unusually important to note that in their defense, the suspects, and after the main trial, the convicts, made a new claim that Rev. Eugen Šutrin was a spy in the Molat Camp. This is actually a statement that indicates the possible real reasons for committing the murder, and not because of the so-called spying but because of the possible fear of his testimony in the

\footnotetext{
58 On the activities and jurisdiction of the Zadar District People's Court, see: Z. Begonja, Okupacija duha: ideološka indoktrinacija u Zadru 1945.-1955., pp. 49-57.

59 HR-State Archives in Zadar, f. 465., Kotarski narodni sud Zadar 1945-1948., box no. 101 200., file Kk 129/46/27, letter no. I 1/45., from March 1, 1946.

60 Ibid., Kk 129/46/28, Indictment no. K 1/1946., from January 16, 1946.

61 Ibid., Kk 129/46/30, Record of the main trial from April 17, 1946.
} 
direction of what was really happening at the Molat Camp. That is why all of the statements obtained and the painted picture of the reasons for the crime should be approached, which also indicated that all of the mentioned possibilities should not be rejected a priori, simply because it would mean, to a large extent, a relativization of events. Simple questions arising from the changing and often complementary allegations of convicts does not allow for all of the facts to be established and therefore make it impossible to place full trust in their statements, which ultimately hinders obtaining an unambiguous view of developments.

The extent to which the doubts in this regard are indeed reasonable can also be determined from the proceedings that followed, and in particular, this refers to the final results. Thus, in the first place, it should be noted that the convicts Curko and Pavlović, appealed to the District People's Court in Zadar through their lawyer Patricija Padelin. Such was the content of the following statement: "It cannot be denied that the act as it happened was difficult in itself, but when sentencing it was necessary to take into account the motives that gave rise to such a terrible crime." ${ }^{\prime 2}$ Then, in the second-instance proceedings, the District People's Court in Zadar held a public hearing in May, where it was decided to reduce the sentence of eight (8) years of loss of civil and political rights to two (2) years, while the majority of the sentence remained the same. ${ }^{63}$ Based on this verdict, on June 14,1946 , the convicts were sent to serve their sentences in Lepoglava. ${ }^{64}$ In the meantime, pursuant to the Decree on Pardon of Military Persons of the Presidium of the National Assembly of the Federal People's Republic of Yugoslavia (FPRY), from 9/V-47 in the criminal case against Pere Curko and Ivan Pavlović Đani, a private session was held at the District People's Court in Zadar on June 11, 1947, and a decision was made granting the convicts "pardon and forgiveness for half of the sentence of imprisonment with forced labor." ${ }^{25}$ The next step in the direction of complete release of the convicts was the decision of the Ministry of the Internal Affairs of the People's Republic of Croatia, which at the end of 1947, granted parole to

\footnotetext{
62 Ibid., Kk 129/46/33, Appeal from May 14, 1946.

63 Ibid., Kk 129/46/34, Judgment of the Zadar District Court kž 37/46., from May 27, 1946.

64 Ibid., Kk 129/46/38, letter from the Department of Internal Affairs at the City Executive Board N.O. Zadar submitted to the Zadar District People's Court, no. 9967/46., from November 30, 1946. Although in letter no. 2338/47, dated June 11, 1947, there is a handwritten supplement stating that Pavlović was taken to Lepoglava and Ćurko to Stara Gradiška.

65 Ibid., Kk 129/46/39, Decision of the District People's Court in Zadar. For the Pardon Decree for military personnel, see: HR-State Archives in Zadar, Službeni list FNRJ, no. 42., May 20, 1947, p. 498.
} 
Curko and Pavlović, and this lasted until the end of the rest of their sentence. ${ }^{66}$ In mid-March of 1948, Pere Curko sent a request for pardon to the Presidium of the Parliament of the People's Republic of Croatia, which was urgently considered in the same month and resolved in his favor. Namely, a decision was made according to which: "the remainder of Pere Curko's unserved sentence of imprisonment with forced labor has been forgiven." ${ }^{\prime 67}$ Not much later, the request of Ivan Pavlović Đani was resolved by the same procedure, and the Presidium issued such a decision to forgive the rest of the unserved sentence in February $1951 .^{68}$

At the end of the sequence of events, it should be noted that the whole range of investigative actions, as well as the testimonies of suspects, that is, convicts, court proceedings, and the acquittal after serving most of the sentence, undoubtedly indicate the regime's actions aimed at finding and mitigating circumstances for their ideological adherents. It is precisely this development that casts serious doubt on the real reasons for committing the crime, as well as on the judicial and political bodies to abide by the law and act indiscriminately.

\section{Concluding remarks}

Eugen Šutrin's life path, which included his upbringing and educational ascent toward a certain goal, was a key reason for choosing the priestly ministry. It was also an indication of the difficulties he would go through because of his commitment, as well as proof of his firmness and unwavering faith in the correctness of what he decided to do. His priestly period, which was mainly related to the events of the War, remained fulfilled primarily by the expression of his sacrifice and commitment to work in order to alleviate the difficulties of the detainees in the Italian concentration camp for civilian internees on Molat. When the War ended, his priestly services took him to Privlaka, where in an atmosphere that was dominated by the communist political passion, he fell victim to two party confidants. The sequence of events continued with the actions of repressive and judicial bodies of the People's government in order to expose those really responsible for the murder of Rev. Eugen Šutrin, but dur-

\footnotetext{
66 Ibid., Kk 129/46/47/48, Decision on parole for Pere Ćurko and Ivan Pavlović Đani, no. 46.748-III-1947. from December 23, 1947.

67 Ibid., Kk 129/46/54, Decision of the Presidium of the Parliament of the People's Republic of Croatia, no. 146/50., from March 28, 1948.

68 Ibid., Kk 129/46/60, Decision of the Presidium of the Parliament of the People's Republic of Croatia, no. 70-1951., from February 13, 1951.
} 
ing its course it also showed their level of infection with ideological principles and on that basis the administrative procedures performed to resolve the case. It is for these reasons that this event left behind certain questions and doubts, simply because it uncritically used the defendants' contradictory statements, whereby the conclusions did not give full meaning to the actual reasons for committing the crime. It remains to be considered whether the act was indeed carried out solely on the basis of the motives cited by the accused, or whether it was the intention to eliminate witnesses to the events that took place at the Camp in Molat.

Reverend Eugen Šutrin paid the price of the time in which it was only worth being on the so-called right side. Any different view or individual assessment, that is, a group of people, was a basic precondition for the actions of the followers that were loyal to the Party, to whom, as in this case, repressive and judicial authorities were added. This example depicts all the subordination of the nomenclature of power to the ideological pattern and their actions according to such given definitions. The best proof of this claim is in the urgent procedures of allowing convicts Pere Curko and Ivan Pavlović Đani to spend as little time as possible in penitentiaries for the crimes they were proven to have committed. The example thus showed how their previous political proselytizing behavior provided a guarantee in such actions of committing a brutal crime, that is, it provided open opportunities for the regime's full understanding towards its followers.

\section{Bibliography}

\section{Unpublished Archival Sources:}

Archives of the Šibenik diocese

Archives of the Zadar Archdiocese (AZDN)

HR- State Archives in Zadar, f. 309., Kotarski komitet KPH Zadar

HR-State Archives in Zadar, f. 465., Kotarski narodni sud Zadar 1945-1948.

\section{Literature:}

Akmadža, Miroslav. Katolička crkva u komunističkoj Hrvatskoj: 1945. 1980. Zagreb - Slavonski Brod, 2013

Batelja, Juraj. Zadarska trilogija, Book 2. Zagreb, 2014 
Begonja, Zlatko. Okupacija duha: Ideološka indoktrinacija u Zadru 1945. - 1955. Zadar, 2021

Begonja, Zlatko. Političke prilike i sudski procesi u Zadru od 1944. do 1948. Doctoral dissertation. Zadar, 2007

Begonja, Zlatko. "Proturječja u svezi s brojem žrtava fašističkog koncentracijskog logora na otoku Molatu", in: Logori, zatvori i prisilni rad u Hrvatskoj/Jugoslaviji 1941. - 1945., 1945. - 1951. Zagreb, 2010, pp. 91-110

Begonja, Zlatko."U Srbu su 27. srpnja napadnuti Hrvati i Hrvatska“, in: Dossier Boričevac, Josip Pavičić, ed. Zagreb, 2012, pp. 226-243

Capogreco, Carlo Spartacco. Mussolinijevi logori - Internacija civila u fašističkoj Italiji (1940. 1943.). Zagreb, 2006

Grbelja, Josip. Talijanski genocid u Dalmaciji - Konclogor Molat. Zagreb, 2004

Kero, Pavao, Pregled povijesti Zadarske nadbiskupije od 1918. do 1948. Zadar, 2006

Kero, Pavao. "Ubijeni i osuđivani svećenici Zadarske nadbiskupije od Drugoga svjetskog rata do Domovinskog rata“, in: Hrvatski mučenici i žrtve iz vremena komunističke vladavine. Zagreb, 2013, pp. 435-458

Klinger, William. Teror narodu: Povijest OZNE, Titove političke policije. Zagreb, 2014

Krišto, Jure. Hrvatski katolički pokret 1903. - 1945. Zagreb, 2004

Krizman, Bogdan. Ante Pavelić i Ustaše. Ljubljana, 1986

Krizman, Bogdan. NDH između Hitlera i Mussolinija. Ljubljana, 1986

Krizman, Bogdan. Ustaše i Treći Reich, books 1 and 2. Ljubljana, 1986

Livaković, Ivo. Poznati Šibenčani: šibenski biografski leksikon. Šibenik, 2003

Lovrovich, Giovanni Eleuterio. Zara dai bombardamenti all'esodo (1943.1947.). S. Lucia di Marino, 1974

Matacin, Fr. Ante. Neke crtice iz moga života i slučaj profesora Draganovića. Ontario, 1968

Matković, Hrvoje. Povijest Jugoslavije: Hrvatski pogled. Zagreb, 1998

Pojava i značenje dr. Ivana Merza u Crkvi u Hrvatskoj. Zagreb, 1979

Radelić, Zdenko. Obavještajni centri: Ozna i Udba u Hrvatskoj (1942. 1954.), Books 1 and 2. Zagreb, 2019

Rječnik historije države i prava. Zagreb, 1968 
Sinovčić, Marko. NDH u svietlu dokumenata. Buenos Aires, 1950 - Zagreb, 1998

Službeni list FNRJ, no. 42., May 20, 1947

Šepić, Dragovan, “Talijanska okupaciona politika u Dalmaciji (1941.-1943.)“, Putovi revolucije (1963.), No. 1-2: 215-241

Šutrin, Rozario. Žrtve bogoljublja i čovjekoljublja. Zadar, 2002

Vrančić, Vjekoslav. Branili smo državu, First book. Barcelona-Munich, 1985

Znidarčić, Lav. "Don Joso Felicinović i Orlovsko-križarska organizacija“, in: Život i djelo don Jose pl. Felicinovića. Pag - Zadar, 2002 